\title{
Laboratory Observations on the Influence of Temperature and Salinity on Development of the Eggs and Growth of the Larvae of Solea solea (Pisces)
}

\author{
M. Fonds \\ Netherlands Institute for Sea Research, Postbox 59, Texel, The Netherlands
}

ABSTRACT: Eggs of the sole Solea solea (L.) were incubated at different constant temperatures $\left(10^{\circ}, 13^{\circ}, 16^{\circ}, 19^{\circ}, 22^{\circ} \mathrm{C}\right)$ and salinities $(10,20,30,40,50 \%)$; the larvae were reared at the same temperatures but at one salinity (30\% S). High survival and normal development to hatching were observed at temperatures from $10^{\circ}$ to $16^{\circ} \mathrm{C}$ and salinities from $20 \%$ to $40 \% \mathrm{~S}$. The growth rate increased with increasing size of the larvae and also increased with the rearing temperature to a maximum at $22^{\circ} \mathrm{C}$. Some environmental factors which may influence the survival of sole eggs and larvae in the sea are discussed.

\section{INTRODUCTION}

In the eastern Atlantic Ocean the common sole Soled solea reaches its northern limit in the North Sea, where the adults occur at depths of about 10 to $60 \mathrm{~m}$ (Bückmann, 1934). North Sea soles migrate in winter offshore to greater depth thus avoiding low water temperatures (Woodhead, $1964 \mathrm{a}, \mathrm{b}$ ); they return in spring to the coastal areas for spawning (Christensen, 1960, Anonymous, 1965; De Veen, 1967, 1970). The pelagic eggs and larvae are transported by the residual currents along the coast (Flüchter, 1970; Riley, 1974), where the young soles start demersal life in shallow areas and in tidal estuaries. The Wadden Sea seems to act as an important nursery for North Sea sole (Zijlstra, 1972). Eggs and pelagic larvae are often found close to the shore but it is still unknown whether the soles actually spawn in the estuaries. It is therefore of interest to know whether estuarine conditions are favourable for the development and survival of eggs and larvae.

In 1976 some soles spawned in a tank in the seawater aquarium of our Institute and produced fertilized eggs. Experiments were carried out to estimate the influence of temperature and salinity on survival and development of the eggs. After hatching, the growth rate of the larvae was determined under various conditions. For a review on cultivation of marine fishes consult 'Marine Ecology' Volume III (Kinne, 1977, p. 968). Temperature and salinity effects on fishes have been reviewed in 'Marine Ecology' Volume I by Brett (1970), Garside (1970), and Holliday (1971).

\section{MATERIAL AND METHODS}

\section{Spawning Stock}

Adult soles Solea solea (L.) (7 males and 7 females) are kept in the laboratory in cylindrical tanks with a diameter of $160 \mathrm{~cm}$ and a depth of $70 \mathrm{~cm}$, containing some 14001 of seawater. The seawater supply is approximately $120 \mathrm{l} \mathrm{h}^{-1}(32 \% \mathrm{~S})$; water temperatures are kept between $15^{\circ}$ and $20^{\circ} \mathrm{C}$ in summer and between $6^{\circ}$ and $12^{\circ} \mathrm{C}$ in winter. The fish are fed with fresh mussel meat (Mytilus) and lugworms (Arenicola). The laboratory has a glass roof to ensure a normal daynight cycle.

From December to February each year females show a rapid development of the ovaries and spawning usually starts in April. After each spawning thousands of eggs, with a diameter of $1.2 \mathrm{~mm}$, float at the surface where they are collected with fine mesh hand nets.

In 1976 spawning started on 2 April at $12^{\circ} \mathrm{C}$; the last spawning was recorded on $3 \mathrm{July}$. In 1977 spawning began on 1 April at $10^{\circ} \mathrm{C}$, in 1978 on 3 March at $11^{\circ} \mathrm{C}$; in both years spawning stopped by the end of June. In 1976 some 24 spawnings were recorded, but only in 9 
cases did fertilization rate appear to reach 30 to $90 \%$. In 1977 and 1978 all eggs remained unfertilized although mature males were present in the tanks. Artificial fertilization of eggs stripped from ripe females, employing chopped testes from freshly caught ripe males from the fishmarket, were unsuccessful (see also Cunningham, 1890). When stripped, a ripe female usually produces about 20000 to 30000 ripe eggs. However, the ovaries contain about ten times as many eggs, which is sufficient for several spawnings with intervals of about 3 to 10 days. The testes of the males are very small $(2-3 \mathrm{~cm})$; this suggests a complicated spawning behaviour and a close sychronization in the pairs to ensure fertilization. Flüchter (1970) observed spawning in the laboratory and describes how male and female swim together at the surface. Such behaviour is frequently observed at night in the North Sea during the spawning migration of soles in spring (De Veen, 1967.)

\section{Incubation of Eggs}

Fertilized eggs from natural spawnings were only obtained in 1976. They were incubated in 14 lightgreen coloured glassfibre-plastic incubation tanks with a size of $60 \times 40 \times 50 \mathrm{~cm}$ depth, which contained seawater with the following temperature-salinity combinations: $10^{\circ} \mathrm{C}(20,30 \% \mathrm{~S}), 13^{\circ} \mathrm{C}(20,30,40 \% \mathrm{~S})$, $16^{\circ} \mathrm{C}(10,20,30,40,50 \% \mathrm{~S}), 19^{\circ} \mathrm{C}(20,30,40 \% \mathrm{~S})$ and $22{ }^{\circ} \mathrm{C}(30 \% \mathrm{~S})$. The constant temperatures varied $0.2^{\circ} \mathrm{C}$ while salinities were kept constant within $2 \mathrm{~S} \%$. Subsamples of 200 eggs from the different spawnings were incubated separately in small black vulcathene cylinders $(8 \mathrm{~cm}$ diameter $\times 10 \mathrm{~cm}$ height) with a plankton gauze bottom ( $1 \mathrm{~mm}$ mesh size), floating by means of polystyrene-foam rings in the incubating tanks. The same incubators have been used successfully in a similar set up for garfish eggs (Fonds et al., 1974). The seawater in the incubation tanks was only aerated, not changed or filtered, and antibiotics were added once a month in concentrations of 25000 I. U. Penicillin $+25 \mathrm{mg}$ Streptomycine per litre. Development of the eggs was recorded daily while dead eggs were removed from the egg holders and survival was roughly estimated.

\section{Rearing of Larvae}

After hatching, some batches of larvae were released from the eggholders into the green incubation tanks at $30 \% \mathrm{~S}$ and reared at constant temperatures of $10^{\circ}$, $13^{\circ}, 16^{\circ}, 19^{\circ}$, and $22^{\circ} \mathrm{C}$. They were fed regularly with sieved natural zooplankton, collected in large outdoor seawater ponds. Samples of larvae were taken from each tank at weekly intervals to estimate the growth rate and to investigate their stomach contents.

\section{Diseases and Parasites}

Since the rearing tanks were not changed or filtered, they became more or less polluted by the end of the rearing experiments and many larvae died. Dying larvae usually floated at the surface, showing a conspicuously pale colour. They often had numerous bladders on the body suggesting infection with fish tuberculosis. On one occasion, in the $13^{\circ} \mathrm{C}$ tank, a larva of $5.6 \mathrm{~mm}$ length was attacked and lethally injured by a very fast swimming pear-shaped ciliate $(0.16 \times 0.05$ $\mathrm{mm})$, probably introduced with the plankton.

\section{Growth of Demersal Stages}

At the end of the experiments all young soles were collected in two asbestos concrete tanks $(120 \times 60 \times$ $30 \mathrm{~cm}$ high) and reared further for several months at ambient seawater temperatures $\left(19^{\circ}-22^{\circ} \mathrm{C}\right)$ with chopped mussel meat as the only food. In the $19{ }^{\circ} \mathrm{C}$ rearing tank two albinos were found.

\section{RESULTS}

\section{Egg Development and Survival}

The embryonic and larval development of Solea solea (L.) has been described by Fabre-Domergue and Biétrix (1905), Rosenthal (1966), Flüchter and Pandian (1968), Flüchter (1970), and Riley (1974). The embryos hatch at an early stage of development when the eggs are still transparent, the mouth and pectoral fins undeveloped. They float upside down at the surface; their size is approximately $3-3.5 \mathrm{~mm}$ total length by 1-1.2 $\mathrm{mm}$ height including the larval fin. The passive yolk-sac larvae develop in a few days into actively swimming larvae of $4-4.5 \mathrm{~mm}$ total length with black pigmented eyes, a well-developed mouth and pectoral fins.

In Table 1 the estimated incubation times to different stages of embryonic development are shown in relation to incubation temperatures. The effect of temperature $\left(\mathrm{T},{ }^{\circ} \mathrm{C}\right)$ on incubation time $(\mathrm{D}, 24 \mathrm{~h})$ can be described by an exponential relation $D=A \cdot T^{B}$, where $A$ refers to the different development stages, while the exponent $B$ is a constant ( $B=1.334$, Table 1 ) describing the temperature effect.

At $22^{\circ} \mathrm{C}$ no viable larvae hatched; at $19^{\circ}$ at least 
Table 1. Solea solea eggs. Estimates of incubation time in days $(D, 24 \mathrm{~h})$ from fertilization to various developmental stages. Eggs were incubated at the different constant temperatures listed

\begin{tabular}{|c|c|c|c|c|c|c|c|c|}
\hline \multirow{2}{*}{ Stage } & \multicolumn{4}{|c|}{ Incubation temperature $T$} & \multirow{2}{*}{$\begin{array}{c}\text { Expon. corr } \\
D \text { with } T\end{array}$} & \multirow{2}{*}{$\begin{array}{c}\text { Corr. coeff. } \\
r(\mathrm{n}=4)\end{array}$} & \multicolumn{2}{|c|}{ Calculated $D$} \\
\hline & $10^{\circ} \mathrm{C}$ & $13^{\circ} \mathrm{C}$ & $16^{\circ} \mathrm{C}$ & $19^{\circ} \mathrm{C}$ & & & $10^{\circ}$ & $16^{\circ}$ \\
\hline 1 & 1.75 & 1.25 & 1.0 & 0.75 & $D=34.4 T^{-1290}$ & 0.997 & 1.76 & 0.96 \\
\hline 2 & 3.0 & 2.25 & 1.75 & 1.25 & $D=66.6 T^{-1.332}$ & 0.991 & 3.10 & 1.66 \\
\hline 3 & 5.25 & 3.75 & 2.75 & 2.25 & $D=114.6 T^{-1338}$ & 0.999 & 5.26 & 2.80 \\
\hline 4 & 6.50 & 4.50 & 3.50 & 2.75 & $D=137.8 T^{-1.329}$ & 0.999 & 6.46 & 3.46 \\
\hline 5 & 11.0 & 8.0 & 6.0 & 4.5 & $D=270.9 T^{-1.383}$ & 0.997 & 11.22 & 5.85 \\
\hline
\end{tabular}

$10 \%$ of the embryos hatched but many were abnormal. At $13^{\circ}$ and $16^{\circ} \mathrm{C}$ survival to hatch was high, at $10^{\circ} \mathrm{C}$ near $100 \%$.

The effect of salinity on egg development is less obvious than of temperature. The eggs and larvae floated in salinities higher than $30 \% \mathrm{~S}$, at salinities below $30 \%$ S they sank to the bottom of the incubators and often showed mortality due to crowding and probably respiratory stress. Apart from this mortality, survival at 20,30 and $40 \%$ S was approximately the same; at $10 \%$ and $50 \% \mathrm{~S}$ survival was clearly reduced and the majority of the larvae produced were abnormal. At $10 \% \mathrm{~S}$ the hatched larvae failed to swim up to the surface to fill their swimbladders and finally died on the bottom of the incubators.

The rate of development was clearly lower at the lower salinities $(10 \%$ and $20 \% \mathrm{~S})$; at the highest salinity $(50 \%$ S) many larvae failed to hatch (approx. $30 \%$. These larvae continued development inside the egg until they suffocated.

Table 2. Solea solea larvae. Length distribution at the end of growth experiments. Dotted lines: beginning of metamorphosis; solid lines: end of metamorphosis

\begin{tabular}{|c|c|c|c|c|c|c|c|c|c|c|}
\hline \multirow{3}{*}{$\begin{array}{c}\text { Total } \\
\text { length } \\
(\mathrm{mm})\end{array}$} & \multirow{3}{*}{$\begin{array}{l}\text { End date: } \\
\text { Temp. }\left({ }^{\circ} \mathrm{C}\right):\end{array}$} & \multicolumn{4}{|c|}{ Started 31 May } & \multicolumn{5}{|c|}{ Started 18 June } \\
\hline & & 8/VII & $5 / \mathrm{VII}$ & $29 / \mathrm{VI}$ & 29/VI & 9/VII & 9/VII & $9 / \mathrm{VII}$ & 8/VII & $8 / \mathrm{VII}$ \\
\hline & & 13 & 16 & 19 & 22 & 10 & 13 & 16 & 19 & 22 \\
\hline $4-5$ & & & & & & 5 & & & 2 & \\
\hline $5-6$ & & & & & & 7 & 8 & 3 & 9 & \\
\hline $6-7$ & & & & & & 2 & 11 & 2 & 6 & \\
\hline $7-8$ & & & 4 & & & & 8 & 9 & 9 & $\underline{1}$ \\
\hline $8-9$ & & 1 & 2 & 1 & & & 6 & 5 & $\underline{7}$ & $\overline{3}$ \\
\hline-10 & & 5 & 4 & $\overrightarrow{4}$ & & & 1 & & $1 \overline{1}$ & 1 \\
\hline-11 & & 8 & 7 & 8 & 3 & & 1 & 1 & 18 & 3 \\
\hline-12 & & 2 & 9 & 9 & 6 & & & 1 & 5 & 3 \\
\hline-13 & & 13 & 14 & 6 & 5 & & & 3 & 6 & 4 \\
\hline-14 & & 13 & 13 & 7 & 7 & & & 1 & 9 & 6 \\
\hline-15 & & 12 & 8 & 8 & 8 & & & 1 & 5 & 1 \\
\hline-16 & & 9 & 6 & 11 & 5 & & & 1 & 3 & 2 \\
\hline-17 & & 10 & 7 & & 8 & & & & 4 & 3 \\
\hline-18 & & 6 & 5 & & 5 & & & & 1 & 2 \\
\hline-19 & & 5 & 2 & 3 & 3 & & & & 1 & 2 \\
\hline-20 & & 3 & 2 & 4 & 3 & & & & & 2 \\
\hline-21 & & & 4 & & 3 & & & & & 1 \\
\hline-22 & & 3 & 1 & & 2 & & & & & 1 \\
\hline-23 & & & 1 & & & & & & & \\
\hline-24 & & & 1 & & & & & & & \\
\hline-25 & & & 3 & 1 & 1 & & & & & \\
\hline-26 & & & 1 & 1 & & & & & & \\
\hline Mean lengtl & $(\mathrm{mm}):$ & 14.9 & 14.9 & 14.1 & 16.0 & 5.6 & 7.2 & 9.1 & 10.8 & 14.5 \\
\hline Standard de & ation: & 2.9 & 4.1 & 3.4 & 3.2 & 0.6 & 1.3 & 1.2 & 3.3 & 3.9 \\
\hline Total numbe & reared: & 195 & 230 & 184 & 82 & 14 & 35 & 28 & 152 & 35 \\
\hline Variance $(\%$ & f mean): & 56 & 113 & 82 & 64 & 6 & 23 & 16 & 101 & 105 \\
\hline
\end{tabular}




\section{Development of Larvae}

Two groups of larvae were reared in the green incubating tanks, a first series from 31 May to 5 July, a second series from 18 June to 9 July (Table 2).

After yolk-sac absorption, the active swimming firstfeeding larvae were $4-4.5 \mathrm{~mm}$ long and $1.5 \mathrm{~mm}$ high including the larval fin. Between 6 to $7 \mathrm{~mm}$ length the development of the finrays started, particularly at the tail, while small or ange spots appeared on the body. At $7 \mathrm{~mm}$ length the larvae showed a conspicuously brown colour and were still symmetric; metamorphosis started at 8 to $9 \mathrm{~mm}$ length. At high temperatures $\left(19^{\circ} \mathrm{C}\right)$, metamorphosis started earlier and the larvae were already fully metamorphosed at $9 \mathrm{~mm}$ length, as compared to $10 \mathrm{~mm}$ for complete metamorphosis at lower temperatures (Table 2). During metamorphosis the 9-mm larvae already spent long periods on the bottom of the tanks, the full change-over from pelagic to demersal life occurred gradually at a size of 9 to $10 \mathrm{~mm}$. After metamorphosis the young soles changed gradually in colour from dark brown to yellowish grey at a size of 11-12 $\mathrm{mm}$.

\section{Food}

Zooplankton was fished with a $200-\mu \mathrm{m}$ meshsize net and sieved over $500 \mu \mathrm{m}$ or $1000 \mu \mathrm{m}$ meshsize to remove unwanted plankters like crab zoeas and jellyfish. Balanoid nauplii were always predominant, followed by copepods, cladocerans (Podon, in spring) and polychaete larvae.

The stomach contents of the sole larvae examined during the rearing experiments are summarized in Table 3. It appears that the larvae preferred polychaete larvae, copepods and cladocerans. Balanoid nauplii were underrepresented in the stomachs considering

Table 3. Solea solea larvae. Stomach contents of individuals reared in the laboratory on natural zooplankton. Balanoid nauplii and copepods dominated in the plankton

\begin{tabular}{|lc|}
\hline Contents & $\begin{array}{c}\text { Numbers of stomachs } \\
\text { examined }\end{array}$ \\
\hline Worm larvae (polychaetes) & 37 \\
Copepods & 24 \\
Cladocerans (Podon) & 19 \\
Balanoid nauplii & 15 \\
Balanoid cyprids & 8 \\
Mollusc veligers & 7 \\
Sand grains & 6 \\
No contents (empty stomachs) & 6 \\
\hline Total number & \\
of stomachs examined: & 85 \\
\hline
\end{tabular}

their abundance in the plankton. According to Last (1978) sole larvae in the sea eat predominantly lamellibranch larvae and dinoflagellates; only larger larvae feed mainly on polychaete larvae.

The dimensions of the open mouth of small $(4-5 \mathrm{~mm})$ sole larvae was approximately $0.20-0.35 \mathrm{~mm}$, the size of the prey in their stomachs measured $0.15-0.25 \mathrm{~mm}$ width by $0.40-0.70 \mathrm{~mm}$ length. Larger larvae $(5-7 \mathrm{~mm})$ had a mouth opening of approximately $0.35-0.70 \mathrm{~mm}$; the prey dimensions were $0.15-0.50 \mathrm{~mm}$ by $0.50-0.70$ $\mathrm{mm}$. These dimensions are difficult to compare with the measurements reported by Last (1978), who estimated mouth openings and stomach contents of Solea solea larvae of $1.5-3 \mathrm{~mm}$ length, well below the length at hatching $(3.5 \mathrm{~mm})$. Although shrinkage of the larvae examined by Last, due to formalin fixation, may have been considerable, the question arises whether Last's material might have contained the smaller larvae of a related sole species, for example of the solenette Buglossidium luteum, a smaller-sized species with very similar larvae and high abundance in the southern North Sea. If from Last's Table 4 only larvae larger than $4 \mathrm{~mm}$ are considered, we may conclude that Solea solea larvae eat mainly dinoflagellates, polychaete larvae, copepods and lamellibranch larvae. This is confirmed by our observations on larvae reared in the laboratory.

\section{Feeding Behaviour}

The feeding behaviour of sole larvae was often closely observed. They usually swam actively about and examined every little particle encountered. When confronted with a potential prey they stopped swimming and floated with the particle - their body bent in an S-shape and ready for attack. The 'picking-on-thebottom' behaviour described by Rosenthal (1966) was not observed in the green rearing tanks, although the larvae tended to stay close to the green walls. Only in a small perspex tank with a sand bottom were some larvae seen picking on the bottom. However, in spite of the zooplankton available their stomachs contained only sandgrains (see Table 3 ).

\section{Growth Rate}

The mean total length of the larvae, from measurements of subsamples taken from the rearing tanks at regular intervals, are plotted against time in Figure 1. Growth rate increased with increasing size of the larvae; a linear fit was obtained when the logarithm of the length $(\log \mathrm{L}, \mathrm{mm})$ was plotted against the larval age in days $(t, 24 \mathrm{~h})$. Hence the length of the larvae can be 


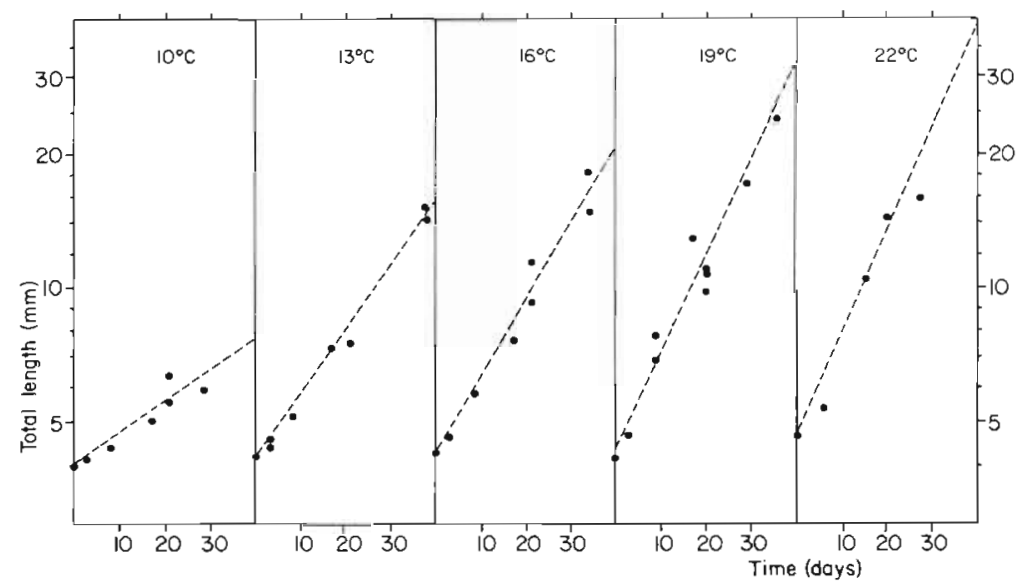

Fig. 1. Solea solea larvae. Growth in length at different temperatures; measurements of subsamples taken at regular intervals. Total length plotted on a log scale against age in days. Dots: mean length

described as a function of time as $L=A . e^{B t}$, where $A$ is the length of the larvae at the start $\left(L_{o}\right.$ at $t=o$ was usually about $4-4.5 \mathrm{~mm}$ in the experiments) and $B$ is a growth-rate coefficient measuring time $t$ in days. How-

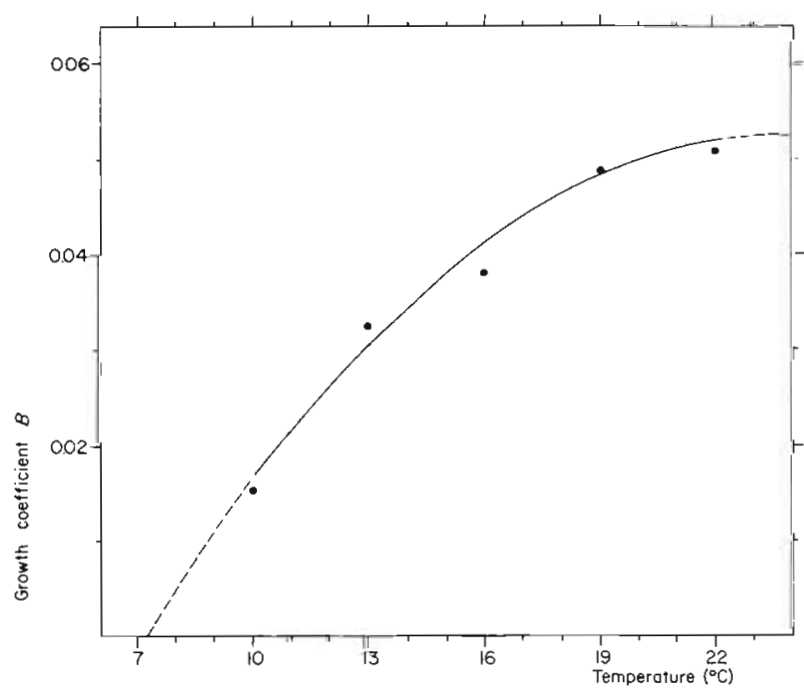

Fig. 2. Solea solea larvae. Relation between rearing temperature and growth coefficient $B$ for growth in length $(L)$ accor-

$$
\text { ding to } L=A \cdot e^{B}
$$

ever, $B$ increases non-linearly with the rearing temperature (Fig. 2), reaching a maximum value of 0.052 at $22{ }^{\circ} \mathrm{C}$. The relation of $B$ with $T\left({ }^{\circ} \mathrm{C}\right)$ can be fitted to a second degree polynomial as follows: $B=0.0092 T$ $0.00019 T^{2}-0.056$. Extrapolation predicts a maximum growth rate at about $23^{\circ}-24^{\circ} \mathrm{C}$ while $B$, and hence growth, is zero at $7{ }^{\circ} \mathrm{C}$. Actually, growth of the larvae at $10^{\circ} \mathrm{C}$ was already very poor and none of these larvae reached metamorphosis which would have taken two months according to our equation.

The increase in growth rate at rearing temperatures from $10^{\circ}$ to $19^{\circ} \mathrm{C}$ is considerable. In Table 4 the mean length for a given age is calculated and Figure 3 illustrates the effect of temperature on the average growth rate and time to metamorphosis. At $22^{\circ} \mathrm{C}$ metamorphosis was completed on average two weeks after the first feeding at a size of $9 \mathrm{~mm}$; at $13^{\circ} \mathrm{C}$ the larvae metamorphosed on average at $10 \mathrm{~mm}$ length after four weeks. The length distribution of the larvae in the tanks at the end of the growth measurements is shown in Table 2 . Growth of young soles after metamorphosis $\left(19^{\circ}-22^{\circ} \mathrm{C}\right.$, chopped mussel) is summarized in Table 5 . The mortality rate of these fish was about $14 \%$ per month, mainly due to bacterial diseases. Such a mortality probably occurs only during the

Table 4. Solea solea larvae. Linear correlation between mean log length ( $L, \mathrm{~mm})$ and age ( $t$, days, $24 \mathrm{~h}$ ) of subsamples reared at different constant temperatures. Parameters are given of the semi-exponential relation $L=A$.e. ${ }^{B i}$, where $A$ is body length at start $(t=o)$, $e$ the base of the natural logarithm, and $B$ a temperature-dependent growth coefficient

\begin{tabular}{|c|c|c|c|c|c|c|c|}
\hline \multirow{2}{*}{$\begin{array}{c}\text { Rearing } \\
\text { temperature } \\
\left({ }^{\circ} \mathrm{C}\right)\end{array}$} & \multirow{2}{*}{$\begin{array}{c}\text { Correlation } \\
\text { coefficient } \\
(r)\end{array}$} & \multirow{2}{*}{$\begin{array}{c}\text { Number of } \\
\text { subsamples } \\
(n)\end{array}$} & \multirow{2}{*}{$\begin{array}{c}\text { Length } \\
\text { at start }\left(L_{0}\right) \\
(A, \mathrm{~mm})\end{array}$} & \multirow{2}{*}{$\begin{array}{c}\text { Growth } \\
\text { coefficient } \\
B\end{array}$} & \multicolumn{3}{|c|}{$\begin{array}{c}\text { Calculated length }(\mathrm{mm}) \\
\text { at the age of }\end{array}$} \\
\hline & & & & & 10 & 20 & 30 days \\
\hline 10 & 0.96 & 7 & 4.00 & 0.0152 & 4.6 & 5.4 & 6.3 \\
\hline 13 & 0.99 & 10 & 4.10 & 0.0325 & 5.7 & 7.9 & 10.9 \\
\hline 16 & 0.99 & 8 & 4.15 & 0.0382 & 6.1 & 8.9 & 13.1 \\
\hline 19 & 0.98 & 9 & 4.40 & 0.0493 & 7.2 & 11.8 & 19.3 \\
\hline 22 & 0.98 & 6 & 4.51 & 0.0510 & 7.5 & 12.6 & 21.1 \\
\hline
\end{tabular}



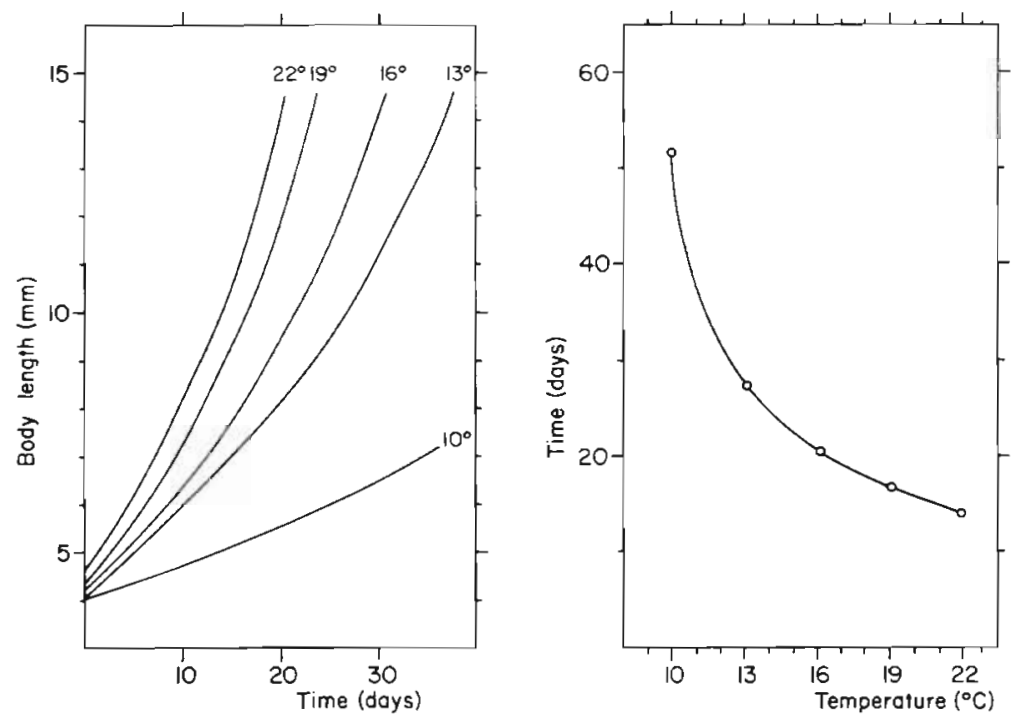

Fig. 3. Solea solea larvae. Calculated growth rate in relation to rearing temperature. Left: Estimated increase in total length. Right: Estimated time from start measurements (feeding larvae) to metamorphosis

juvenile stage, larger soles usually show little mortality in the laboratory.

\section{DISCUSSION}

\section{Spawning}

In the North Sea soles usually start reproduction at water temperatures of $7^{\circ}-8^{\circ} \mathrm{C}$. They may start in March along the Belgian coast (Van de Velde, 1975) and late April along the Dutch coast; where spawning continues through May and Junge (Anonymous, 1965; De Veen, 1970). In the laboratory the soles spawned early (1-2 April 1976, 1977, 1 March 1978). This indicates that in the North Sea low water temperatures (below $7^{\circ} \mathrm{C}$ ) may delay spawning.

\section{Egg Development}

The rate of egg development is strongly dependent on water temperature, particularly between $10^{\circ}$ and
$16{ }^{\circ} \mathrm{C}$, the actual temperature range in the North Sea in late spring. The temperature limits for development of sole eggs have been estimated by Flüchter (1970): $7^{\circ}-19^{\circ} \mathrm{C}$, Riley (1974): $7^{\circ}-15^{\circ} \mathrm{C}$ (after gastrulation $6^{\circ}-20^{\circ} \mathrm{C}$ ), and Irvin $(1974): 7^{\circ}-17^{\circ} \mathrm{C}$. All authors agree on a lower limit at $7^{\circ} \mathrm{C}$. Survival of the eggs at the higher temperature limit probably depends also on other factors like the thermal history of the parent fish, the developmental stage of the eggs, the oxygen supply etc., which may explain the different values obtained.

Riley (1974) calculated the exponential relation between incubation temperature $\left(T,{ }^{\circ} \mathrm{C}\right)$ and the incubation time in days $(D)$ for the development of sole eggs to various stages. In the relation $D=A T^{B}$ the exponent $B$ varied between -1.2852 and -1.588 for the different stages, with a mean value of -1.3965 $(\mathrm{S} . \mathrm{E} .=0.1046)$. Our estimates of $B$, shown in Table 1 (on average 1.334) agree reasonably well with those of Riley,

The eggs of Solea solea can develop successfully to feeding larvae at saìnities between 20 and $40 \% \mathrm{~S}$.

Table 5. Solea solea. Growth after metamorphosis; $19^{\circ}-22^{\circ} \mathrm{C}$, mussel meat as food

\begin{tabular}{|c|c|c|c|c|c|}
\hline Date & & Number of fish & $\begin{array}{l}\text { Length range } \\
\text { (cm) }\end{array}$ & $\begin{array}{l}\text { Mean length } \\
(\mathrm{cm} \pm \mathrm{S} . \mathrm{D} .)\end{array}$ & $\begin{array}{l}\text { Relation of length }(L) \text { to } \\
\text { height }(H) \text { or to weight ( } W \text { ) }\end{array}$ \\
\hline \multirow[t]{5}{*}{1976} & 9/VII & 513 & $0.5-2.5$ & $1.3 \pm 0.4$ & \\
\hline & $21 / \mathrm{XX}$ & 444 & $2-10$ & $5.3 \pm 1.5$ & $L / H=2.347 \pm 0.026$ \\
\hline & & & fish selected, & fish discarded & \\
\hline & $21 / \mathrm{IX}$ & 63 & $7-10$ & $7.9 \pm 0.8$ & selected fast growers \\
\hline & 14/XII & 44 & $8-12$ & $10.6 \pm 1.1$ & $W=0.0033 L^{3.457}(r=0.98)$ \\
\hline \multirow[t]{2}{*}{1977} & $2 / I I I$ & 37 & $12-18$ & $15.0 \pm 1.4$ & \\
\hline & $17 / \mathrm{IV}$ & 29 & $15-21$ & $17.2 \pm 1.7$ & $W=0.0027 L^{3492}(I=0.98)$ \\
\hline
\end{tabular}


Higher salinities interfere with the hatching process and lower salinities slow down the rate of development. Although the eggs still develop to hatching at $10 \% \mathrm{~S}$, the larvae cannot survive at this salinity. This may explain why soles reach a limit in their eastward distribution in the Belt area (Johansen, 1916; Lindquist, 1970). Moreover, the eggs tend to sink at salinities below $30 \% \mathrm{~S}$, which does not appear to be particularly favourable for survival.

\section{Growth of Larvae}

The growth rate of the pelagic larvae shows a strong positive correlation with water temperatures from $10^{\circ}$ to $16^{\circ} \mathrm{C}$, the normal temperature range in North Sea coastal areas in late spring. The temperature range for successful development of the eggs $\left(7^{\circ}\right.$ to $\left.19^{\circ} \mathrm{C}\right)$ is lower than that for growth of the larvae $\left(10^{\circ}\right.$ to $\left.23^{\circ} \mathrm{C}\right)$. Hence, during development the operational temperature range seems to shift to higher values, in agreement with conditions in nature for a spring spawner (cf. Irvin, 1974).

\section{Environmental Factors}

The main factors which may influence the survival of sole larvae in the sea are probably temperature, food, predation, and transport to the nurseries.

Temperature influences the beginning of the spawning season and therefore also the growth season for the juveniles. Besides, the rate of development of the eggs and the growth rate of the larvae increase with the temperature. Hence, high- or rapidly increasing temperatures in spring shorten the duration of the pelagic stage. This is probably favourable considering the high mortality rate at that stage (Riley, 1974).

Food. The spring phytoplankton bloom in the southern North Sea usually starts in March and continues until the end of May (Gieskes and Kraay, 1975, 1977), while zooplankton is most abundant in April to July (Fransz, personal communication). Pelagic sole larvae are usually found from April-May until June (Last, 1978) during a period of abundance of zooplankton, hence food shortage is unlikely. However, the availability of zooplankton for the larvae is probably strongly dependent on weather conditions, particularly wind and cloud cover. The behaviour of the sole larvae in rearing tanks indicate that they catch their prey by sight (Rosenthal, 1966). This confirms the observation by Last (1978) that sole larvae in the sea only feed during day time (see also Fuchs, 1978). It is evident that they need a minimum amount of light to find their food in a way similar to plaice larvae (Blaxter, 1969,
1972). Cloud cover diminishes underwater visibility in the sea, while strong winds bring silt and detritus in suspension in the coastal areas which reduces visibility even more. Under such conditions it will become difficult for the sole larvae to select their plankton prey from the thousands of silt particles.

Predation. The slow-swimming sole larvae are conspicuously brown-coloured and probably an easy prey for active predators. However, the most abundant pelagic predators are jellyfishes like species of Phialidium, Pleurobrachia, Beroë, Aurelia and Cyanea (Fransz et al., 1978), which are quite capable of catching fish larvae (Lebour, 1922, 1923). When underwater visibility is low and turbidity high, due to cloud cover and strong wind, the sole larvae will have less chance to avoid such passive predators.

Transport. The transport of the nearly metamorphosed larvae to the nurseries might be influenced by the wind direction affecting the currents in shallow coastal areas. However, according to Rauck (1974), the time of arrival and subsequent yearclass strength of 0 group plaice in spring in the German Wadden Sea is mainly correlated with the water temperature, not with the wind vector. The immigration and settling of sole larvae in the coastal nurseries probably takes place in the same way as has been described for plaice larvae by Creutzberg et al. (1978).

Table 6. Solea solea. Possible effects of abiotic environmental faciors on growth and survival of larvae in sea

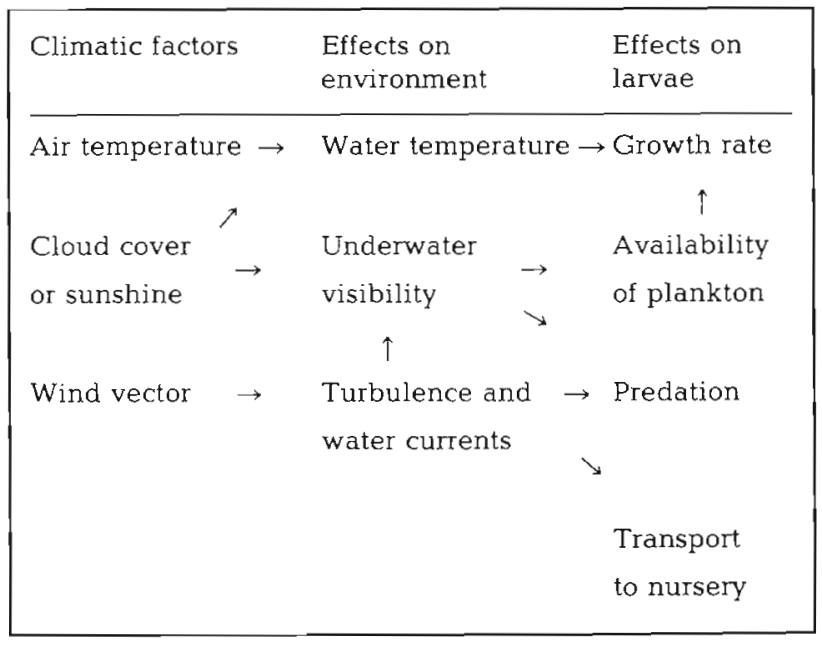

Finally, some possible relations between climatic factors, biological factors, and survival of sole larvae are summarized in Table 6. This simplistic scheme suggests that warm sunny springs, such as those in 1975 and 1976, are more favourable for the survival of sole larvae than cold windy springs such as prevailed in 1977 and 1978. However, the success of a yearclass depends also, if not mainly, on the survival of demersal 
young during their first year in the nursery (Bergman et al., 1976; Rauck and Zijlstra, 1978). A severe winter may wipe out a whole yearclass of 0 -group soles.

Solea solea is a southern species which thrives best at temperatures between $16^{\circ}$ and $22{ }^{\circ} \mathrm{C}$ (Fonds, $1975_{i}$ Fonds and Saksena, 1977). Its reproduction in spring in coastal areas provides for optimum conditions for growth and survival of the juveniles: (1) higher and rapidly increasing temperatures in spring; (2) rich food supply for pelagic larvae (particularly polychaete larvae); (3) vicinity of nurseries with a rich food supply for demersal young.

For marine fish species which spawn in lagoons and estuaries, low salinities are, in general, not particularly favourable (Fonds et al.,1974; Fonds and van Buurt, 1974). Salinity probably acts mainly as limiting factor, particularly in the range of 5 to $10 \% \mathrm{~S}$.

\section{LITERATURE CITED}

Anonymous (1965). Report of the working group on sole I. C. E. S. Coop. Res. Rep., 5, 1-126.

Bergman, M., Kuipers, B., Spliethoff, P. and van der Veer, H. (1976). Garnalen en krabben ais mogelijke predatoren van 0-jarige schol op het Balgzand. Visserij, 29, 432-438.

Blaxter, J. H. S. (1969). Visual thresholds and spectral sensitivity of flatfish larvae. J. exp. Biol., 51, 221-230.

Blaxter, J. H. S. (1972). Brightness discrimination in larvae of plaice and sole. J. exp. Biol., 57, 693-700.

Brett, J. R. (1970). Temperature: animals: fishes: functional responses. In O. Kinne (Ed.), Marine Ecology, Vol. I, Environmental Factors. Wiley, London. pp. 515-560.

Bückmann, A. (1934). Untersuchungen über die Naturgeschichte der Seezunge, die Seezungenbevölkerung und den Seezungenfang in der Nordsee. Ber. dt. wiss. Kommn Meeresforsch., 7, 49-114.

Christensen, J. M. (1960). The stock of soles (Solea solea) and the sole fishery on the Danish North Sea coast. Meddr Danm. Fisk-og Havunders., 3, 19-53.

Creutzberg, F., Eltink, A. Th. G. W. and van Noort, G. J. (1978). The migration of plaice larvae (Pleuronectes platessa) into the western Wadden Sea. In D. S. McLusky and A. J. Berry (Eds), Proceedings of the 12th European Symposium on Marine Biology, Stirling, Scotland. Pergamon Press, Oxford. pp. 243-251.

Cunningham, T.J. (1890). Studies on the reproduction and development of Teleostean fishes occurring in the neighbourhood of Plymouth. J. mar. biol. Ass. U.K., 1, 10-54.

De Veen, J (1967). On the phenomenon of soles (Solea solea L.) swimming at the surface. J. Cons. int. Explor. Mer, 31, $207-236$.

De Veen, J. (1970). On some aspects of maturation in the common sole, Solea solea (L.). Ber. dt. wiss. Kommn Meeresforsch., 21, 78-91.

Fabre-Domergue, P. and Biétrix, E. (1905). Developpement de la sole (Solea vulgaris). Trav. Lab. Zool. Marit. Concarneau, 1905, 1-214.

Flüchter, J. (1970). Zur Embryonal- und Larvalentwicklung der Seezunge, Solea solea (L.). Ber. dt. wiss. Kommn Meeresforschung, 21, 369-376.

Flüchter, J. and Pandian, T. J. (1968). Rate and efficiency of yolk utilization in developing eggs of the sole, Solea solea (L.). Helgoländer wiss. Meeresunters., 18, 53-60.

Fonds, M. (1975). The influence of temperature and salinity on growth of young sole, Solea solea (L.). In G. Persoone and E. Jaspers (Eds), Proceedings of the 10th European Symposium on Marine Biology, Ostende, Belgium, Vol. 1. Universa Press, Wetteren. pp. 109-125.

Fonds, M. and van Buurt, G. (1974). The influence of temperature and salinity on development and survival of Goby eggs (Pisces, Gobiidae). Hydrobiol. Bull. (Amsterdam), 8, 110-116.

Fonds, M., Rosenthal, H. and Alderdice, D. F. (1974). Influence of temperature and salinity on embryonic development, larval growth and number of vertebrae of the Garfish Belone belone. In J. H. S. Blaxter (Ed.), The Early Life History of Fish. Springer, Heidelberg. pp. 509-525.

Fonds, M. and Saksena, V. P. (1977). The daily food intake of young soles (Solea solea L.) in relation to their size and the water temperature. Actes de Colloques C.N.E.X.O. (Brest, France), 4, 51-58.

Fransz, H. G., Ottema, M. and Seip, P. A. (1978). Abundance and growth of fish larvae during the summer decline of copepod populations in Dutch coastal waters of the North Sea and possible interactions with jellyfish and ctenophores. Counc. Meet., int. Counc. Explor. Sea (= C.M.I.C.E.S.), L:19, 1-9 (Mimeo).

Fuchs, J. (1978). Influence de la photoperiode sur la croissance et la survie de la larve et du juvenile de sole (Solea solea) en elevage. Aquaculture, 15, 63-74.

Garside, E. T. (1970). Temperature: animals: fishes: structural responses. In O. Kinne (Ed.), Marine Ecology, Vol. I, Environmental Factors. Wiley, London. pp. 561-616.

Gieskes, W. W. C. and Kraay, G. (1975). The phytoplankton spring bloom in Dutch coastal waters of the North Sea. Neth. J. Sea Res., 9, 166-196.

Gieskes, W W. C. and Kraay, G. (1977). Continuous plankton records: changes in the plankton of the North Sea and its eutrophic southern bight from 1948 to 1975. Neth. J. Sea. Res., 11, 334-364.

Holliday, F. G. T. (1971). Salinity: animals: fishes. In O. Kinne (Ed.), Marine Ecology, Vol. I, Environmental Factors. Wiley, London. pp. 515-560.

Irvin, D. N. (1974). Temperature tolerance of developmental stages of Dover sole (Solea solea L.). In J. H. S. Blaxter (Ed.), The Early Life History of Fish. Springer, Heidelberg. pp. 449-464.

Johansen, A. C. (1916). Marking experiments with sole (Solea vulgaris) and Turbot (Scophthalmus maximus L.) in the Kattegat and Baltic waters. Meddr Kommn Havunders, (Ser. Fisk.), 5, 1-18.

Kinne, O. (1977). Cultivation of animals - research cultivation. In O. Kinne (Ed.), Marine Ecology, Vol. III, Cultivation, Part 2. Wiley, Chichester. pp. 579-1293.

Last, J. M. (1978). The food of four species of Pleuronectiform larvae in the eastern English Channel and southem North Sea. Mar. Biol, 45, 359-368.

Lebour, M. (1922). The food of plankton organisms. I. $J$. mar. biol. Ass. U.K., 12, 644-677.

Lebour, M. (1923). The food of plankton organisms. II. J. mar. biol. Ass. U.K., 13, 70-92

Lindquist, A. (1970). On the distribution of fish eggs and larvae in the Skagerrak during the months May and June. Biol. Rep., Inst. mar. Res. Lysekil, 19, 5-82.

Rauck, G. (1974). The arrival of different groups of young plaice in the German Wadden Sea. Ber. dt. wiss. Kommn Meeresforsch., 23, 273-288

Rauck, G. and Zijlstra, J. J. (1978). On the nursery aspects of 
the Wadden Sea for some commercial fish species and possible long-term changes. Rapp. P.-v. Réun. Cons. int. Explor. Mer, 172, 266-275.

Riley, J. D. (1974). The distribution and mortality of sole eggs (Solea solea L.) in inshore areas. In J. H. S. Blaxter (Ed.), The Early Life History of Fish. Springer, Heidelberg. pp $39-52$.

Rosenthal, H. (1966). Beobachtungen über das Verhalten der Seezungenbrut. Helgoländer wiss. Meeresunters., 13, $213-288$

Van de Velde, J. (1975). Investigations on eggs and larvae of various fish species along the Belgian coast in 1972 and 1973. Ann. biol., Cons. perm. int. Explor. Mer, 30, 198-199.
Woodhead, P. M. J. (1964a). The death of North Sea fish during the winter of $1962 / 63$ particularly with reference to the sole, Solea vulgaris. Helgoländer wiss. Meeresunters. $10,283-300$

Woodhead, P. M. J. (1964b). Changes in the behaviour of the sole, Solea vulgaris, during cold winters and the relation between the winter catch and sea temperatures. Helgoländer wiss. Meeresunters., 10, 328-342.

Zijlstra, J. J. (1972). On the importance of the Wadden Sea as a nursery area in relation to the conservation of the southern North Sea fishery resources. Symp. zool. Soc. London, $29,233-258$.

This paper was presented by Dr. H. Rosenthal; it was accepted for printing on June 29, 1979. 